\title{
OPTIMALISASI DISKUSI KELAS MELALUI PEER ASSESSMENT DAN SELF ASSESSMENT UNTUK MENILAI KEMAMPUAN KOMUNIKASI LISAN MAHASISWA CALON GURU BIOLOGI
}

\author{
Aa Juhanda \\ Pendidikan Biologi Universitas Muhammadiyah Sukabumi \\ J1. R. Syamsudin, S.H, No. 50, Kota Sukabumi \\ E-mail: aajuhanda@gmail.com
}

\begin{abstract}
This descriptive study aimed to obtain oral communication skills prospective biology teachers through peer and self assessment in class discussions. Subjects were 26 students of Biology Education Department $6^{\text {th }}$ semester 2015/2016 academic year who contracted the courses of anatomy and physiology of the human body. The instrument used consisted of sheets of peer and selfassessment, as well as the student questionnaire. The result of research showed that the average of peer assessment for oral communication of students is different with the mean of self assessment. The spoken oral communication ability indicators that was revealed include: (1) choosing the most appropriate way to present the explanation of 66\% (Good); (2) using tables, drawings, models to present an explanation of $62 \%(\mathrm{Good}) ;(3)$ responds to a question from another student in the form of a convincing argument of $64 \%$ (Good); (4) interpret the obtained solution by $51 \%$ (Enough); (5) responds to a question from another student in the form of a convincing argument of 57\% (Enough). Students responded positively to the implementation of peer and self assessment in lectures.
\end{abstract}

\section{Keywords : Peer Assessment, Self Assessment, Classroom Discussions, Oral Communication}

\begin{abstract}
Perubahan paradigma dalam proses pembelajaran yang tadinya berpusat pada dosen menjadi pembelajaran yang berpusat pada mahasiswa diharapkan dapat mendorong mahasiswa untuk terlibat secara aktif dalam membangun pengetahuan, sikap dan perilaku. Melalui proses pembelajaran dengan keterlibatan aktif mahasiswa ini berarti dosen tidak mengambil hak
\end{abstract}

mereka untuk belajar dalam arti yang sesungguhnya. Dalam proses pembelajaran yang berpusat pada siswa (Student Center Learning), mahasiswa dapat memperoleh kesempatan dan fasilitas untuk membangun sendiri pengetahuannya sehingga mereka akan memperoleh pemahaman yang mendalam, dan pada akhimya dapat meningkatkan mutu kualitas mahasiswa. Adapun 
metode pembelajaran yang dapat mengembangkan kegiatan seperti itu adalah diskusi kelas.

sebuah riskusi kelas merupakan pembelajaran kelompok yang masingmasing kelompok yang ditentukan mendapat tanggung jawab untuk mendiskusikan sesuai dengan tema/ masalah/judul pembelajaran yang telah ditetapkan oleh dosen dan mereka selanjutnya akan membuat kesimpulan atau catatan kecil yang berisikan tuangan pikiran atau pendapat dari kelompok tersebut, dan itu menjadi tugas sekretaris kelompok kemudian diserahkan oleh ketua kelompoknya kepada guru/dosen yang bersangkutan (Siswoyo, 2013).

Dalam diskusi kelas, seringkali mahasiswa saling menanggapi jawaban temannya atau berkomentar terhadap jawaban yang diajukan oleh mahasiswa lain. Demikian pula mereka kadangkadang mengundang anggota kelompok lain untuk bicara mengutarakan pendapatnya. Kemampuan berkomunikasi mahasiswa yang ditunjukkan pada saat kegiatan diskusi sangat penting dikembangkan dalam pembelajaran sains. Kecakapan tersebut mencakup kemampuan untuk menjelaskan ideide ilmiah dan konsep kepada audiens yang bervariasi baik secara formal maupun nonformal (Miles, 2010). Lebih lanjut, Harlen (1992) berpendapat bahwa komunikasi lisan merupakan merupakan salah satu dari keterampilan proses sains yang penting untuk dilatihkan pada mahasiswa dalam pembelajaran sains.

Menurut Zuharman (2007) perubahan paradigma pendidikan dari teacher centred $\mathrm{ke}$ arah student centred tidak hanya membawa dampak terhadap metode dan aktifitas belajar, melainkan juga terhadap cara penilaian hasil belajar. Sedangkan Firman (2000) mengemukakan bahwa ditinjau dari segi pendidikan, pengalaman, interaksi dengan mahasiswa dalam kelas, maka dosen menempati posisi penting untuk menilai keefektifan program pengajaran yang dikelolanya. Adanya reformasi dalam bidang pendidikan membuat para dosen harus mengevaluasi dan menata kembali cara mereka menjalankan proses pendidikan. Pergeseran fokus pembelajaran dari dosen ke mahasiswa (learner-centered) dan lifelong learning adalah perubahan sifat dari tujuan pembelajaran dewasa ini. Peer assessment (penilaian teman) dan self-assessment (penilaian diri) merespon perubahan ini dengan sangat baik. Adanya kedua penilaian ini dalam kegiatan diskusi kelas maka diharapkan mahasiswa bisa memiliki kemampuan menilai dan mengevaluasi diri sendiri yang biasanya dilakukan oleh dosen sehingga tentu saja fokusnya bukan lagi kepada dosen, tetapi kepada mahasiswa itu sendiri.

Peer dan self assessment merupakan cara penilaian hasil belajar yang berpusat pada siswa. Metode penilaian ini dapat diterapkan untuk menilai kemampuan non kognitif mahasiswa yaitu untuk mengetahui kemampuan komunikasi lisan mahasiswa saat diskusi kelas dengan menggunakan teknik presentasi. Oleh karena itu, penerapan peer assesment dan self assesment ini dapat dikatakan sebagai penilaian formatif. Zariski (1996) menjelaskan bahwa keuntungan dari peer 
assessment dan self assessment yaitu mendorong siswa untuk memiliki rasa tanggung jawab terhadap proses belajarnya sehingga siswa dapat mandiri, melatih keterampilan mengevaluasi yang berguna untuk lifelong learning dan mendorong deep learning.

\section{METODE}

Penelitian ini menggunakan metode deskriptif. Subjek yang digunakan dalam penelitian ini adalah mahasiswa Pendidikan Biologi semester 6 tahun ajaran 2015/2016 sebanyak 26 orang yang mengontrak mata kuliah anatomi fisiologi tubuh manusia. Pemilihan subjek dilakukan dengan menggunakan teknik purposive sampling. Penelitian ini dilakukan selama 4 bulan terhitung mulai dari bulan Maret sampai Juli 2016. Pengambilan data dilakukan dengan menggunakan lembar peer dan self assessment serta angket siswa. Adapun pengolahan data lembar peer dan self assessment dengan menggunakan rumus Purwanto (2009) .

$$
\mathrm{NP}=\mathrm{R} / \mathrm{SM} \times 100 \%
$$

Tahap selanjutnya dilakukan kategorisasi berdasarkan rumus Arikunto (2010) seperti ditunjukkan pada Tabel 1 .

Tabel 1. Kategori persentase peer dan self assessment

\begin{tabular}{cc}
\hline Persentase & Predikat \\
\hline $81-100 \%$ & Baik Sekali \\
$61-80 \%$ & Baik \\
$41-60 \%$ & Cukup \\
$21-40 \%$ & Kurang \\
$<21 \%$ & Kurang Sekali \\
\hline
\end{tabular}

Adanya data self assessment yang diperoleh selanjutnya digunakan untuk memvalidasi temuan skor mahasiswa pada peer assessment. Nilai persentase untuk setiap indikator kemampuan komunikasi lisan mahasiswa merupakan hasil rerata dari nilai persentase yang terdapat pada peer dan self assessment. Selain itu, untuk pengolahan hasil angket digunakan rumus persentase menurut Sudjana (2010) sebagai berikut:

Persentasetanggapansiswa = Jumlahjawabansiswa Ya Tidak Jumlahselumuhsiswa

Adapun interpretasi jawaban angket dengan cara membuat kategori untuk setiap kriteria berdasarkan Tabel 2 aturan Sudjana (2010).

Tabel 2. Kriteria persentase angket

\begin{tabular}{cc}
\hline Persentase & Kategori \\
\hline $0 \%$ & Tidak satupun \\
$1 \%-30 \%$ & Sebagian kecil \\
$26 \%-49 \%$ & Hampir setengahnya \\
$50 \%$ & Setengahnya \\
$51 \%-80 \%$ & Sebagian besar \\
$81 \%-99 \%$ & Hampir seluruhnya \\
$100 \%$ & Seluruhnya \\
\hline
\end{tabular}

HASIL DAN PEMBAHASAN

1. Kemampuan Komunikasi Lisan Siswa

Pada penelitian ini, kemampuan komunikasi lisan difasilitasi dengan menggunakan metode diskusi kelas melalui presentasi. Kemampuan ini diukur dengan menggunakan lembar observasi yang di dalamnya terdapat lima indikator beserta rubrik penilaiannya. Lembar observasi ini terdiri dari lembar peer assessment dan self assessment. Lembar peer assessment digunakan oleh 
mahasiswa untuk menilai kegiatan presentasi yang dilakukan oleh temannya. Lembar self assessment digunakan oleh mahasiswa yang sudah melakukan presentasi. Tujuan adanya lembar self assessment ini adalah untuk memvalidasi temuan terhadap hasil penilaian yang dilakukan oleh temannya melalui peer assessment. Adapun hasil persentase antara peer assessment dan self assessment mahasiswa calon guru mengenai kemampuan komunikasi lisan yang terukur pada lima konsep yang berbeda seperti ditunjukkan pada Tabel 3.

Tabel 3. Kesesuaian peer dan self assessment kemampuan komunikasi lisan mahasiswa

\begin{tabular}{|c|c|c|c|c|c|c|}
\hline \multirow{3}{*}{$\begin{array}{l}\text { No. } \\
\text { Siswa }\end{array}$} & \multirow{3}{*}{ Konsep } & \multirow{2}{*}{\multicolumn{2}{|c|}{$\begin{array}{c}\text { Peer Assessment } \\
\text { Komunikasi Lisan }\end{array}$}} & \multirow{2}{*}{\multicolumn{2}{|c|}{$\begin{array}{c}\text { Self Assessment } \\
\text { Komunikasi Lisan }\end{array}$}} & \multirow{3}{*}{ Ket. } \\
\hline & & & & & & \\
\hline & & Persentase & Kategori & Persentase & Kategori & \\
\hline 1 & \multirow{4}{*}{$\begin{array}{c}\text { Sistem } \\
\text { Pernapasan }\end{array}$} & 73 & Baik & 67 & Baik & Sesuai \\
\hline 2 & & 61 & Baik & 87 & Baik Sekali & Tidak Sesuai \\
\hline 3 & & 62 & Baik & 67 & Baik & Sesuai \\
\hline 4 & & 84 & Baik Sekali & 53 & Cukup & Tidak Sesuai \\
\hline 5 & \multirow{5}{*}{$\begin{array}{l}\text { Sistem } \\
\text { Saraf }\end{array}$} & 52 & Cukup & 60 & Cukup & Sesuai \\
\hline 6 & & 55 & Cukup & 80 & Baik & Tidak Sesuai \\
\hline 7 & & 35 & Cukup & 87 & Baik Sekali & Tidak Sesuai \\
\hline 8 & & 57 & Cukup & 73 & Baik & Tidak Sesuai \\
\hline 9 & & 57 & Cukup & 53 & Cukup & Sesuai \\
\hline 10 & \multirow{5}{*}{$\begin{array}{c}\text { Sistem } \\
\text { Pencernaan }\end{array}$} & 53 & Cukup & 60 & Cukup & Sesuai \\
\hline 11 & & 57 & Cukup & 33 & Kurang & Tidak Sesuai \\
\hline 12 & & 49 & Cukup & 67 & Baik & Tidak Sesuai \\
\hline 13 & & 59 & Cukup & 80 & Baik & Tidak Sesuai \\
\hline 14 & & 48 & Cukup & 60 & Cukup & Sesuai \\
\hline 15 & \multirow{6}{*}{$\begin{array}{l}\text { Sistem } \\
\text { Urinaria }\end{array}$} & 52 & Cukup & 53 & Cukup & Sesuai \\
\hline 16 & & 50 & Cukup & 67 & Baik & Tidak Sesuai \\
\hline 17 & & 52 & Cukup & 80 & Baik & Tidak Sesuai \\
\hline 18 & & 52 & Cukup & 67 & Baik & Tidak Sesuai \\
\hline 19 & & 50 & Cukup & 67 & Baik & Tidak Sesuai \\
\hline 20 & & 46 & Cukup & 47 & Cukup & Sesuai \\
\hline 21 & \multirow{6}{*}{$\begin{array}{l}\text { Sistem } \\
\text { Endokrin }\end{array}$} & 52 & Cukup & 60 & Cukup & Sesuai \\
\hline 22 & & 62 & Baik & 47 & Cukup & Tidak Sesuai \\
\hline 23 & & 53 & Cukup & 67 & Baik & Tidak Sesuai \\
\hline 24 & & 52 & Cukup & 60 & Cukup & Sesuai \\
\hline 25 & & 67 & Baik & 60 & Cukup & Tidak Sesuai \\
\hline 26 & & 52 & Cukup & 73 & Baik & Tidak Sesuai \\
\hline & cata & 56 & Cukup & 64 & Baik & Tidak Sesuai \\
\hline
\end{tabular}


Pada Tabel 3 ditemukan bahwa kemampuan komunikasi lisan yang diungkap menggunakan peer dan self assessment pada kegiatan diskusi teknik presentasi ini menunjukkan nilai persentase yang berbeda-beda untuk setiap mahasiswanya. Adanya hasil tersebut menandakan bahwa metode diskusi teknik presentasi dapat memfasilitasi dalam memunculkan kemampuan komunikasi lisan siswa. Effendi (2003) mengungkapkan bahwa komunikasi lisan dapat berupa penyampaian informasi secara langsung salah satunya melalui kegiatan presentasi atau diskusi. Akan tetapi, hasil rerata nilai peer assessment untuk komunikasi lisan mahasiswa berbeda dengan hasil rerata nilai self assessment-nya. Self assessment menunjukkan kategori yang baik dibandingkan dengan kategori peer assessmet yaitu cukup. Ini menunjukkan bahwa mahasiswa cenderung menilai dirinya lebih dibandingkan dari kemampuan yang dimilikinya. Temuan ini sejalan dengan pendapat Suwandi (2011) bahwa salah satu kekurangan dari self assessment adalah cenderung akan membaik-baikkan hasil penilaian terhadap dirinya sendiri. Oleh karena itu, hanya sebanyak 10 mahasiswa $(38,46 \%)$ yang sudah memiliki kesesuaian antara penilaian peer assessment dengan self assessmentnya dengan kategori baik dan cukup. Sedangkan sebanyak 16 mahasiswa (61,54\%) dikatakan belum mampu melakukan penilaian seperti ini. Hal itu menunjukkan bahwa tidak semua siswa dalam suatu kelas bisa melakukan penilaian tersebut dengan baik dan mahasiswa belum mengetahui kelebihan dan kelemahan yang ada pada dirinya. Menurut Brown (1994) mengungkapkan bahwa para mahasiswa dikatakan berhasil menjalankan yang terbaik apabila mereka paham akan kelebihan dan kelemahan diri mereka sendiri (Wasis, 2013). Adapun hasil kesesuaian tersebut dapat digambarkan dalam bentuk Gambar 1.

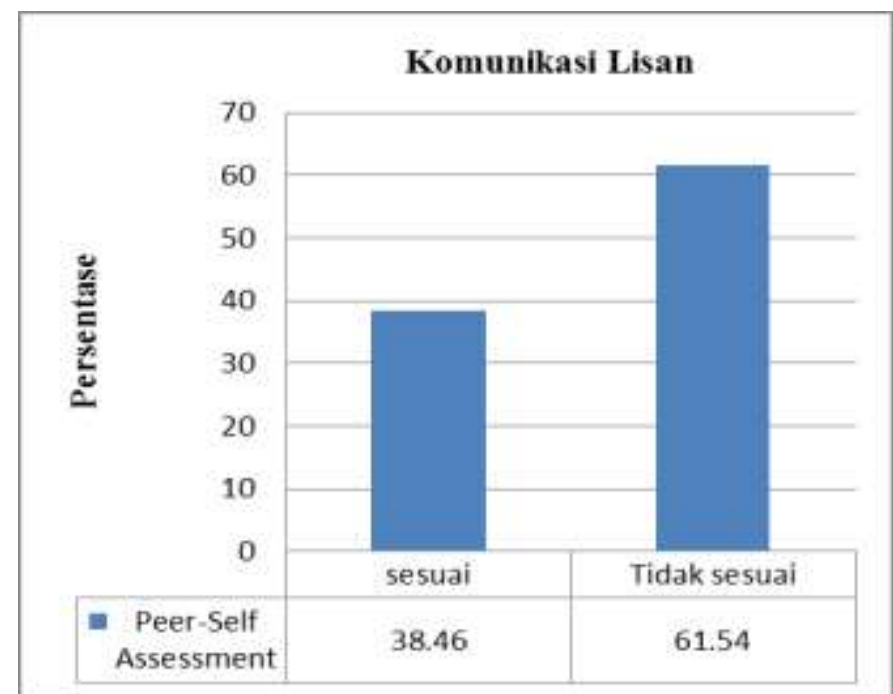

Gambar 1. Kesesuaian peer-self assessment dalam komunikasi lisan 
Pada capaian setiap indikator kemampuan komunikasi lisan yang dimiliki oleh mahasiswa calon guru merupakan hasil rerata dari nilai persentase peer dan self assessment.
Capaian rerata tersebut memuat lima indikator kemampuan komunikasi lisan menurut Suzana (2009) yang ditunjukkan oleh Gambar 2.

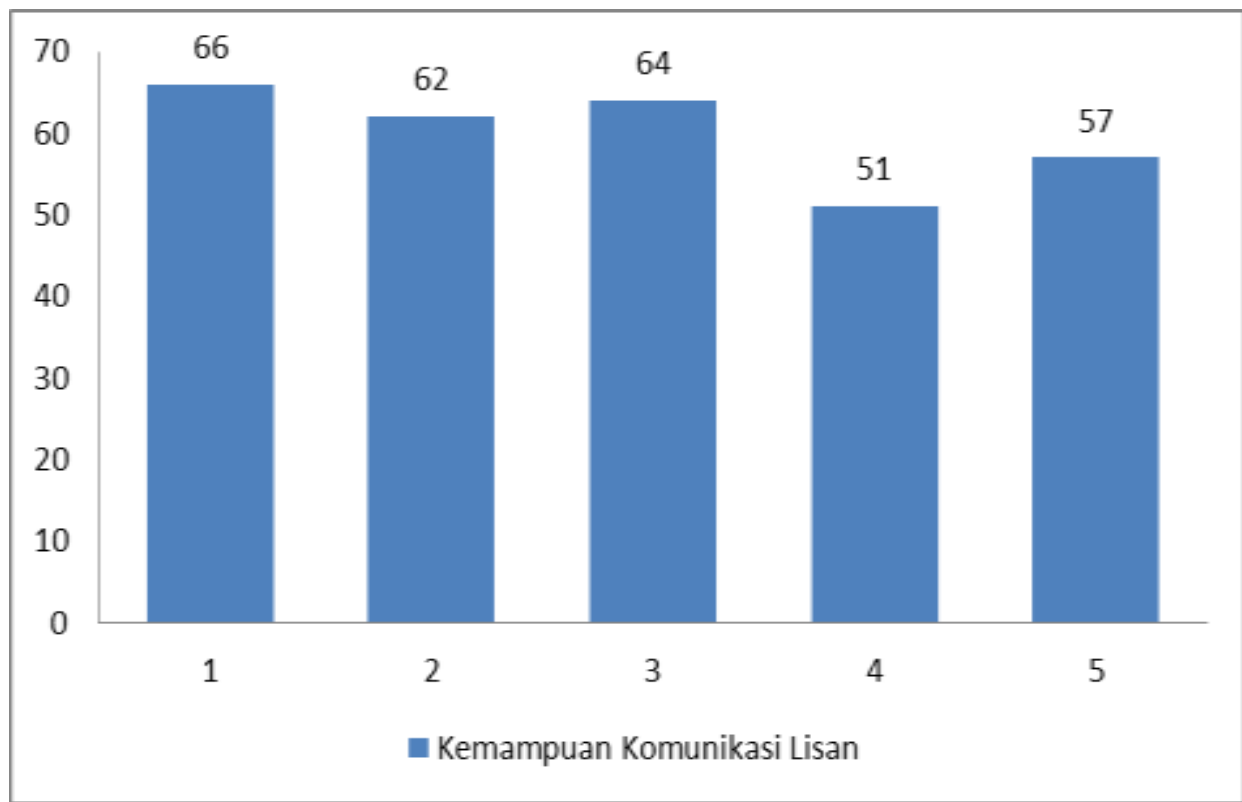

Gambar 2. Rerata persentase indikator kemampuan komunikasi lisan mahasiswa berdasarkan peer-self assessment

Keterangan : (1) Memilih cara yang paling tepat dalam menyampaikan penjelasannya, (2) Menggunakan tabel, gambar, model untuk menyampaikan penjelasannya, (3) Merespon suatu pertanyaan dari siswa lain dalam bentuk argument yang meyakinkan, (4) Menafsirkan solusi yang diperoleh, (5) Merespon suatu pertanyaan dari siswa lain dalam bentuk argument yang meyakinkan.

Gambar 2 menunjukkan bahwa secara umum kemampuan komunikasi lisan mahasiswa pada setiap indikator dapat terungkap melalui penilaian peer dan self assessment selama diskusi kelas dengan rerata persentase yang berbeda-beda. Indikator kemampuan komunikasi lisan yang memiliki rerata persentase paling tinggi yaitu pada indikator ke-1 yaitu memilih cara yang paling tepat dalam menyampaikan penjelasannya sebanyak 66\% (Baik). Pada indikator ini mahasiswa diharapkan dapat menyampaikan materi dengan jelas, sistematis dan mudah dipahami. Sedangkan indikator yang memiliki rerata persentase paling rendah dicapai oleh indikator ke-4 yaitu menafsirkan solusi yang diperoleh sebanyak $51 \%$ (Cukup). Pada indikator ini, mahasiswa dituntut agar mampu menjelaskan solusi yang masuk akal sesuai materi dan menafsirkan solusinya. Adanya temuan ini maka mahasiswa sudah memiliki kemampuan komunikasi 
lisan yang mutlak dimiliki olehnya. Menurut Depdiknas (2002) kecakapan berkomunikasi merupakan kecakapan hidup sosial yang sangat penting dimiliki oleh mahasiswa untuk bekal hidup di masyarakat.

\section{Respon Mahasiswa terhadap Pembelajaran Yang Dilakukan}

Untuk memperoleh respon mahasiswa terhadap pembelajaran yang dilakukan maka digunakan lima pernyataan angket dalam mengungkapnya.

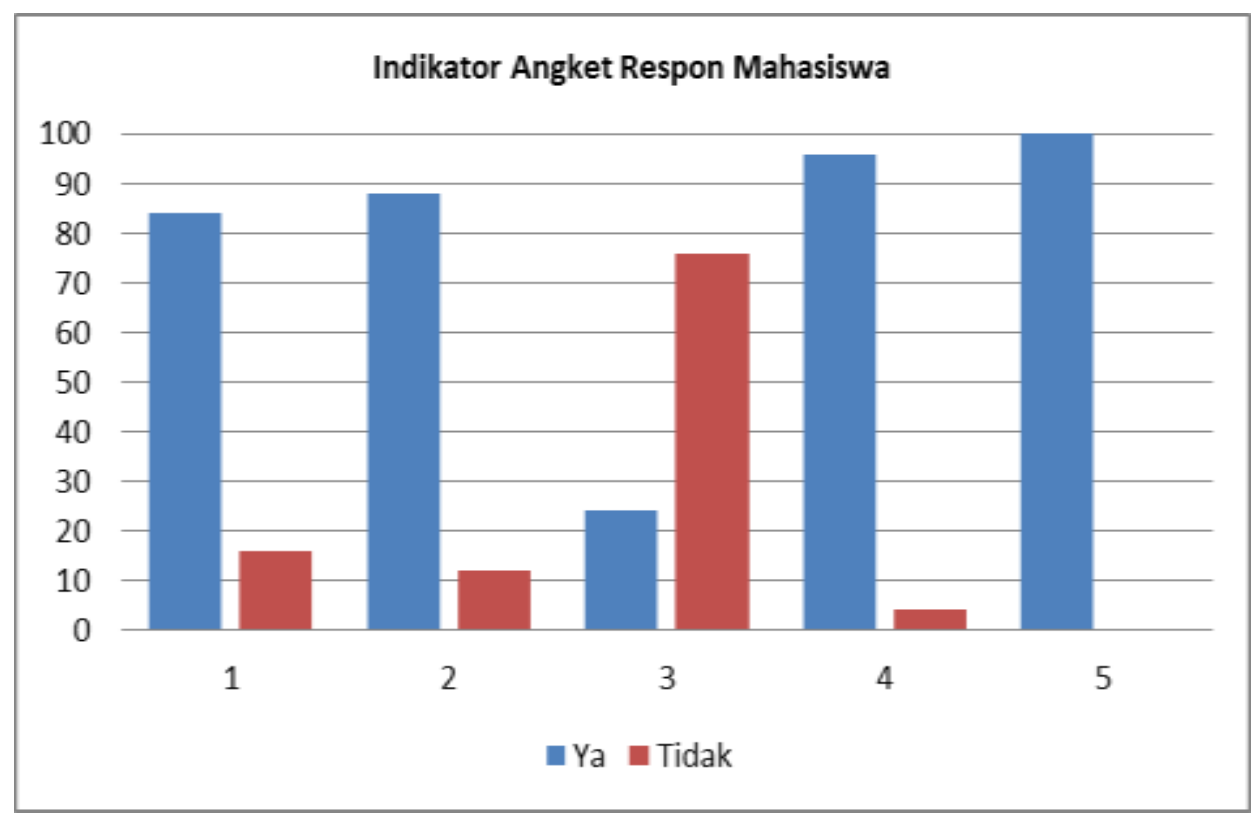

Gambar 3. Respon mahasiswa terhadap pembelajaran yang dilakukan

Keterangan : (1) Ketertarikan melakukan penilaian peer-self assessment ; (2) Peer-self Assessment dapat memotivasi belajar; (3) Peer-self Assessment membebani; (4) Metode diskusi teknik presentasi dapat mengungkap ide/pendapat terkait masalah; (5) Peer-self assessment dan metode diskusi teknik presentasi dapat mengembangkan komunikasi lisan.

Pada gambar 3, terlihat bahwa secara umum mahasiswa calon guru biologi memberikan tanggapan positif terkait pembelajaran yang dilakukan. Hampir seluruhnya mahasiswa calon guru merasa tertarik dan termotivasi dengan pembelajaran peer dan self assessment. Dengan adanya ketertarikan dan motivasi terhadap penilaian tersebut maka diharapkan dapat menimbulkan tanggung jawab dalam belajarnya. Sesuai dengan Zariski (1996) bahwa keuntungan dari peer dan self assessment yaitu, mendorong siswa untuk memiliki rasa tanggung jawab terhadap proses belajarnya sehingga siswa dapat mandiri, melatih evaluation skill yang berguna untuk lifelong learning dan mendorong deep learning.

Peer dan self assessment yang dilakukan tidak membebani mahasiswa dalam pembelajaran. Hanya sebagian kecil (24\%) mahasiswa calon guru merasa repot dan terbebani saat melakukan peer 
dan self assessment karena disaat bersamaan mereka harus memperhatikan temannya presentasi dan menilai. Selain itu hampir seluruh (98\%) mahasiswa memberikan penjelasan bahwa dengan metode tersebut dapat mengungkap ide/pendapat terkait masalah yang disajikan. Morgan menegaskan bahwa diskusi yang ideal adalah berpartisipasinya sekelompok individu dalam diskusi terhadap suatu masalah yang memerlukan informasi atau tindakan lebih lanjut (Suprayitno, 2007).

Seluruh mahasiswa calon guru berpendapat bahwa penilaian peer dan self assessment dan metode diskusi teknik presentasi dapat mengembangkan kemampuan komunikasi lisan dan pemahaman konsep. Ini ditandai oleh sebanyak $100 \%$ mahasiswa memberikan jawaban "ya" terkait hal tersebut. Dalam berdiskusi, terjadi sebuah proses tukar pikiran antara dosen dan mahasiswa atau antara mahasiswa dan mahasiswa lainnya sehingga kemampuan komunikasi setiap mahasiswa dapat terukur. Selain itu, penjelasan yang disampaikan oleh mahasiswa dalam diskusi dapat menjadi parameter keluasaan pemahaman konsep yang dimilikinya. Adanya penilaian peer dan self assessment ini diharapkan dapat mengoptimalkan dari kegiatan diskusi tersebut. Sejalan dengan Orsmond (dalam Kusminto, 2013) menyatakan bahwa Mendorong adanya diskusi antara siswa dan guru. Selain itu, Wahyuni \& Ibrahim (2012) mengemukakan bahwa model peer assessment ini sekaligus sebagai arena belajar karena ketika ia melakukan penilaian, pada hakikatnya ia juga sedang belajar mempertajam wawasan tentang hal yang ia nilai.

\section{SIMPULAN DAN SARAN}

Berdasarkan hasil pembahasan secara keseluruhan, penelitian ini dapat disimpulkan bahwa kemampuan komunikasi lisan mahasiswa calon guru dapat diungkap secara baik melalui peer assessment dan self assessment. Selain itu, mahasiswa calon guru biologi memberikan respon positif terkait pelaksanaan penilaian tersebut.

\section{DAFTAR PUSTAKA}

Arikunto, S. (2010). Dasar-dasar Evaluasi Pendidikan (Edisi Revisi). Jakarta: Bumi Aksara.

Depdiknas. (2002). Pendidikan Berorientasi Kecakapan Hidup (Life Skills) melalui Pendekatan Broad-Based Education (Draft). Jakarta: Departemen Pendidikan Nasional.

Effendi, O. (2003). Ilmu, Teori, dan Komunikasi. Bandung: Citra Aditya Bakti.

Firman, H. (2000). Penilaian Hasil Belajar dalam Pengajaran Kimia. Bandung: Jurusan Penididikan Kimia FPMIPA UPI.

Harlen, W. (1992). The Teaching of Science. London: David Fulton Publisher.

Kusminto, J. B. P. (2013). Analisis Penilaian Kinerja Dengan Teknik Self Assessment Sebagai Evaluasi Kinerja Mahasiswa Pada Praktikum 
Fisika Dasar II Tadris Fisika IAIN Walisongo Semarang. Phenomenom Jurnal Pendidikan MIPA, Vol. 3, No. 2, 75-102.

Miles, E. (2010). In-Service Elementary Teachers' Familiarity, Interest, Conceptual Knowledge, and Performanceon Science Process Skills. Retrieved Juni 23, 2017, from http://ajte.education.ecu.edu.a u/ISSUES/PDF/211/Foulds.pd f.

Purwanto, N. (2009). Prinsip-Prinsip dan Teknik Evaluasi Pengajaran. Bandung: Remaja Rosdakarya.

Siswoyo, R. (2013). Implementasi Model Pembelajaran Diskusi Kelas. Retrieved Desember 23, 2015, from http://rudisiswoyo89.blogspot. co.id/2013/11/implementasimodel-pembelajarandiskusi.html.

Sudjana, N. (2010). Metode Statistika. Bandung: Tarsito.

Suprayitno, T. (2007). Sosiologi Pendidikan. Malang: Universitas Islam Negeri.

Suwandi, S. (2011). Model-Model Asesmen dalam Pembelajaran. Surakarta: Yuma Pustaka.
Suzana, A. (2009). Pengaruh Penerapan Model Reciprocal Learning Terhadap Peningkatan Kemampuan Komunikasi Matematik. Skripsi FPMIPA UPI. Bandung: Tidak Diterbitkan.

Wahyuni, S. \& Ibrahim, S. (2012). Asesmen Pembelajaran Bahasa. Bandung: Refika Aditama.

Wasis, H. S. (2013). Penerapan Self Assesment (Penilaian Diri) Pada Kegiatan Praktikum Untuk Meningkatkan Hasil Belajar Siswa Kelas X Sman 1 Sidayu. Jurnal Inovasi Pendidikan Fisika, Vol. 2, No. 3, 139-142.

Zariski, A. (1996). Student Peer Assessment In Tertiary Eduction: Promise, Perils And Practice. Retrieved Desember 22, 2015, from http://cleo.murdoch.edu.au/asu /pubs/tlf/tlf96/zaris189.html.

Zulharman. (2007). Self dan Peer Assessment Sebagai Penilaian Formatif dan Sumatif. Retrieved Desember 20, 2015, from http://zulharman79.wordpress. com. 